\title{
Increasing the Number of Sponsored Mexican Graduate Students in Engi- neering
}

\author{
Mrs. Maria Claudia Alves, Texas A\&M University
}

Maria Claudia Alves Baudier Director for Engineering International Programs at Texas A\&M University Ms. Maria C. Alves is the Director for Engineering International Programs at Texas A\&M University. She has been in this position since July 2012. In this position she is responsible for internationalizing the research and education activities of the Dwight Look College of Engineering. Under her leadership the college has increased the number of students studying abroad, established new models of study abroad including co-op and research abroad and established meaningful connection for research and attraction of funded international graduate students. Maria started working at Texas A\&M in 2005 as Assistant Director for Latin American Programs and in 2009 she was promoted to Program Manager for South America in the same office. During her time at the Office for Latin America Programs she created, managed and developed projects to enhance the presence of Texas A\&M University in Latin American and to support in the internationalization of the education, research, and outreach projects of the university. She was charged with the development and implementation of a strategic plan for Texas A\&M in South America. While at the Office for Latin America Programs, Maria was also responsible for the opening of the Soltis Center in Costa Rica. Maria speaks three languages fluently (Spanish, Portuguese and English). Maria completed her undergraduate studies at Lynn University in Florida, where she graduated with honors in Business Administration in 2002. She was part of the tennis team and was the team captain for two years, including the year the team was NCAA National Champion in 2001. She is a December 2003 graduate of the MS-Marketing program at Texas A\&M University. And in the Fall of 2009, Maria started the PhD program in Higher Education Administration and is expected to conclude the program in 2015.

\section{Ms. Meghan M. Alexander, Texas A\&M University}

Meghan M. Alexander is the assistant director for Engineering International Programs at Texas A\&M University. She has an M.Ed. in Counseling and over 15 years experience in international education and partnerships.

\section{Mr. Victor Manuel Camara-Poot, Yucatan Government Ministry of Education}

A graduate of the Masters in Government and Public Policy by te Universidad Autónoma de Yucatán (UADY), workink since 2 years ago as Head of the Department of Planning and Strategic Projects at the Department of Higher Education in the Ministry of Education of the Yucatan Government in Mexico .

Throughout his career he has worked in entrepreneurial activities, training of entrepreneurs, development of strategic projects , national and international academic links .

$\mathrm{He}$ is currently part of the team developing a draft international links for the development of scientific and technological activity in Yucatan from the local government with the Texas A \& M University and the government of France with crosscutting issues such as the training of human resources senior, teachers and scientists, among others.

\section{Ing. Martha Elena Ortega, CANIETI}

Martha Ortega is Attetion to Principal Partners and Special Projects Director of the Mexican Electronics Telecommunications and Information Technologies Industries Chamber(CANIETI, for its acronym in Spanish)

She, along with CANIETI senior staff, are looking forward to find the way to increase the number of mexican professionals trained in the latest technologies and greater economic potential.

Martha Ortega is an Computer Systems Engineer by the "Instituto Tecnológico de Mérida" and has a Master degree en Information Technologies Management. 


\section{Increasing the Number of Sponsored Mexican Graduate Students in Engineering Colleges in the United States}

\section{Introduction}

The presence of international students in graduate degree programs in American universities brings a variety of benefits to those institutions including developing international ties, securing financial resources, adding diversity to the intellectual pool of students and fulfilling a shortage of engineering talent in the US ${ }^{[1]}$. However, competition for recruiting these students has increased in the past few years with Australia, the UK and Germany attracting a large number of talented students ${ }^{[1]}$. Several approaches have been reported to ensure the number of international students on campuses does not decline ${ }^{[2]}$, including collaborations, increased efforts in recruitment, and commitment to new funding for marketing and program promotion ${ }^{[3]}$. These are good strategies, however, according to Srivastava et al (2010) "there is a need for coordinated efforts to get the best quality international students" [1]; and to have international recruiting as part of the strategic plan of the university and as a link to economic or social development.

This paper presents a case study of one such coordinated effort - to increase the enrollment of high quality students from Mexico into the Dwight Look College of Engineering (Look College) of Texas A\&M University. The effort started with a pilot program that was implemented during summer 2014 in partnership and with the sponsorship of two Mexican states, Yucatan and Zacatecas, and CANIETI (Cámara Nacional de la Industria Electrónica de Telecomunicaciones y Tecnologías de la Información de Mexico - Information Technology, Telecommunications and Electronic Industry Chamber of Commerce of Mexico). CANIETI's goal is to improve the human capital development in Mexico's information technology sector. One approach to achieve this goal is to send Mexican students to pursue master and PhD degrees in the United States. For Yucatan and Zacatecas, the motivation was similar. These states want to improve human capital development and have scholarships from the Mexican government to sponsor Mexican students to pursue master or $\mathrm{PhD}$ degrees abroad. However, due to lack of awareness or preparedness of the students, those scholarships were not being used completely.

Even though Mexico and the United States are neighbors with strong economic ties, according to data from CONACYT (Consejo Nacional de Ciencia y Tecnología de México), out of 242 sponsored students in the information technology area who were selected to study abroad in 2014, only 25 students came to the United States (About 10\%) ${ }^{[4]}$. The goal of the Look College is to diversify its international student population from strategic countries that are of economic and social importance for the university, the state of Texas and the United States. Although the Look College of Texas A\&M University is very large, with geographical closeness to Mexico, during fall 2013, only 32 graduate students from Mexico were enrolled in engineering programs out of the 1,958 international graduate engineering students enrolled (less than $2 \%)^{[5]}$. The challenges both sides face in increasing the numbers of Mexican graduate students in United States' universities are twofold: first, the language barrier with students not meeting TOEFL and GRE requirements and second, the lack of contact with faculty members at host universities. The pilot program consisted of 50 students selected by CANIETI and the two states, Yucatan and Zacatecas. Those students were enrolled in intensive English classes in the morning, a GRE 
workshop twice a week in the afternoon, and engaged in research under the supervision of a faculty member in the afternoon. This pilot program went beyond traditional marketing efforts by allowing faculty members and students the opportunity to work together before committing to admission, providing tools for students to overcome language and test barriers, and acclimating students to the US graduate student lifestyle, thus once admitted, the adaptation phase is easier and faster.

The pilot program has shown good results. Out of the 50 students who participated in the 2014 summer program, eight students have been admitted and are currently enrolled as sponsored students for the 2015 spring semester for their master or PhD degrees at Texas A\&M University. Two students have already been admitted for fall 2015 and 15 additional students are in the process of completing their application for the fall 2015 semester at Texas A\&M University.

This paper describes the recruiting and selection process of the students, program implementation and the results of the pilot program. Insights into this project can serve as a model for international student recruitment for this and other institutions.

\section{Literature Review}

The 2014 IIE Open Doors report shows that the number of international students on US campuses increased $8.1 \%$ during the 2013/2014 academic year and the trend is for this growth to continue ${ }^{[6]}$. According to this same report, expenditure on tuition and living expenses of international students contribute approximately $\$ 27$ billion dollars to the US economy and almost $80 \%$ of international students' primary funding comes from sources outside of the US ${ }^{[6]}$.

Even though international students play an important role in United States campuses and economy, Becker and Kolster (2012) stated that "the United States has no comprehensive national policy in regards to recruiting international students or the internationalization of higher education" ${ }^{[7]}$ in Özturgut, 2013 (page 2). They continued saying that even though the United States receives a large number of international students at its universities, on a per capita basis the numbers do not look as promising, especially considering that the best and the richest universities in the world are in the United States ${ }^{[7]}$ in Özturgut, 2013. As stated by Özturgut (2013), the points presented above show the need for rethinking some of practices of recruiting and retaining international students in United States universities ${ }^{[3]}$. Brown (2009) explains that there is an intensified competition for international students and this has put pressure on the institutions to "improve their product and to develop internationalization strategies to attract international students and to provide an environment in which domestic and international students can benefit from their confrontation with diversity” ${ }^{[8]}$ (p. 439) in Özturgut, 2013.

One issue in international recruiting in the United States that has been happening since 1983, according to Goodwin and Nacht (1983), is that universities in the United States admit international students seeking their financial contribution and do not consider how these international students fit within their institutions ${ }^{[9]}$ in Özturgut, 2013. And according to Özturgut (2013) this is still happening ${ }^{[3]}$. A reason why this continues to be an issue may be a gap in the literature with the lack of papers describing best practices on recruiting and retaining international students ${ }^{[3]}$. Considering that, in 2013 Özturgut (2013) implemented a study to look 
into this issue and wrote an initial study on those best practices. The summary of the results are below:

Best Practices in Recruiting International Students that emerged from Özturgut (2013)'s study on international student recruitment are: 1. Providing academic support and utilizing campus resources; 2. Attending and participating in international education fairs and recruitment events; 3. Partnering with other organizations for recruiting (colleges and universities, non-profit and governmental institutions, high schools, for-profit organizations); 4. Passive Marketing such as web advertisingonline, brochures and booklets, and others; 5. Utilizing staff and faculty; 6. Utilizing alumni; 7. Utilizing agents; and 8. Snowballing or word-of-mouth ${ }^{[3]}$.

Best Practices in Retaining International Students that emerged from the data on Özturgut (2013)'s study and the review of relevant literature are: 1. International Student \& Scholar Services Staff; 2. Academic Programming and Support, 3. Social and Cultural Engagement and Support; and 4. Financial Aid, Health Services, Religious Support, and Immigration Support ${ }^{[3]}$.

Although there are plenty of reasons to recruit international students including increasing internationalization, bringing additional economic resources to campuses, helping train and develop future international leaders, among others; there is no simple model to recruit international students ${ }^{[3]}$. Research indicates that for a long time institutions have utilized agents as one of the recruiting strategies, however, online marketing is now considered to be the most common method showing significant results ${ }^{[3]}$. Another popular method is the participation of faculty and staff in recruiting events and fairs ${ }^{[3]}$. According to Özturgut (2013), one of the most effective methods is involving faculty members in the recruiting and retention of international students because they have frequent contact with international students on campus ${ }^{[3]}$. Hence, it is imperative to involve the faculty members on the development of international student recruitment and retention plan ${ }^{[3]}$.

At Texas A\&M University, as in most Tier-I research institutions, international recruitment on the graduate level is departmental rather than institutional. The example described by Katz (2006) at Purdue University, where the departmental recruiting strategies are determined by the chair, the head of the graduate program, the graduate committee on admissions, and some individual professors ${ }^{[10]}$, is also true at Texas A\&M University. The result of this decentralized effort is that some departments employ a more passive approach only sending marketing material abroad, while others have active recruiting strategies. There is a lack of an institutionally coordinated effort. Although it may be true that graduate students come to a department and not to an institution, according to Katz (2006), universities are increasingly aware that to succeed, the recruiting initiative cannot remain entirely decentralized ${ }^{[10]}$. An example of such coordinated efforts is a program implemented by Purdue called Graduate Recruitment Overseas (GRO) ${ }^{[10]}$. GRO is a three-year trial grant competition for overseas recruiting trips supported by the provost's office with an allocation of $\$ 60,000^{[10]}$.

Two additional examples of coordinated efforts follow. First are programs or campuses institutions in the United States are establishing in foreign countries ${ }^{[10]}$. For example, the 
University of Buffalo opened a branch in Singapore in 2003 for bachelor and master level programs in business and communications ${ }^{[10]}$. Other examples are the presence of American universities in Education City, Qatar or Knowledge Village, Dubai ${ }^{[10]}$. The second are formal agreements with overseas universities to facilitate the successful transfer of students without duplication of course work, which can provide another source of students coming to the United States ${ }^{[10]}$.

\section{International Graduate Students Recruiting Strategy - A Partnership Program}

As shown in the literature review above, best practices in recruiting international students according to Özturgut (2013) are: 1. Providing academic support and utilizing campus resources; 2. Attending and participating in international education fairs and recruitment events; 3 . Partnering with other organizations (colleges and universities, non-profit and governmental institutions, high schools, for-profit organizations); 4. Passive Marketing such as Web advertising-online, brochures and booklets; 5. Utilizing staff and faculty; 6. Utilizing alumni; 7. Utilizing agents; and 8. Snowballing or word-of-mouth ${ }^{[3]}$. This case study will present and describe a new best practice in strategic partnership programs. It involves some of the elements mentioned in the literature including partnership and faculty involvement.

Texas A\&M University, and more specifically the Look College, increasingly attract qualified international graduate students. In fall 2009, the Look College received 4,656 international masters and doctoral applications, admitted 1,419 and enrolled $530^{[11]}$. Compared to fall 2014, 7,975 applications were received (71\% increase), 1,567 (10\% increase) were admitted and 701 (32\% increase) enrolled ${ }^{[11]}$. However, the administration of the Look College has made the decision to focus more on strategically recruiting the best students and to diversify its international student population. According to the Open Doors report (2014) the number of international students at colleges and universities in the United States increased 8.1\% to 886,052 during the $2013 / 14$ academic year ${ }^{[6]}$. This growth was primarily driven by a $16.5 \%$ increase in Chinese student enrollment in the United States to a total of nearly 235,597 students ${ }^{[6]}$. Making the Chinese students be $31 \%$ of the total international student population, and China the leading sending country. India comes next representing $11.6 \%$ of all international students in US higher education ${ }^{[6]}$. This is not different at the Look College and therefore demonstrates the need for diversification. Mexico was defined not only as a strategic priority but also identified as one of the primary countries to increase student enrollment. During the fall 2013 semester, at the Look College, although a very large college of engineering with geographical closeness to Mexico, only 32 graduate engineering students from Mexico were enrolled out of 1,958 international engineering students (less than $2 \%)^{[5]}$.

CANIETI has the ambitious goal to improve the human capital development of the information technology sector in Mexico. One method for CANIETI to achieve this goal is by sending Mexican students to pursue master and PhD degrees in the United States. While Mexico and the United States are neighbors with strong economic ties, according to CONACYT out of the 242 sponsored students in 2014, only 25 students who were selected to study abroad, came to the United States (about 10\%) ${ }^{[4]}$. The challenges both sides face increasing the numbers of Mexican graduate students in US universities are twofold: first, the language barrier with students not meeting TOEFL and GRE requirements, and second, the lack of contact with faculty members at 
host universities. With that goal in mind - to increase the number of sponsored Mexican master and $\mathrm{PhD}$ students in US institutions in the area of information technology - a program was jointly designed by CANIETI, the state of Yucatan and the Look College. The program consisted of an intensive summer program for selected students, where students would study English in the morning and conduct research in the afternoon. CANIETI in Mexico secured funding from different governmental organizations, including the states of Yucatan and Zacatecas, and the Look College at Texas A\&M University designed a tailored program balancing academic and research preparation with on-campus integration.

The pilot program took place during summer 2014 with 50 students who were selected by CANIETI. Those students were enrolled in English classes in the morning, a GRE workshop twice a week for two hours in the afternoon, and engaged in research under the supervision of a faculty member in the afternoon. This pilot program went well beyond the usual marketing efforts by allowing faculty members and the students the opportunity to work together before committing to admission, providing the tools for students to overcome the language and test barriers, and engaging students in the lifestyle of being a graduate student in the United States acclimating them so once admitted, the adaptation phase is easier and faster. Below we describe how the pilot program unfolded, the results and adjustments being implemented for the summer 2015 program.

\section{Recruiting and Selection}

Discussions about the program began in February 2014 and on May 26, 2014 the 50 students arrived on campus for the 10 -week pilot program. Due to time constraints of the pilot program, recruitment and selection were completed quickly. CANIETI, in partnership with Yucatan and Zacatecas, made an open call in their states and selected students from more than 100 applications received. An unofficial TOEFL was requested from the participants, and a series of in-person interviews took place to select the 50 students.

\section{Program Implementation}

Once the 50 students were selected and the names and profiles of the students given to the Look College (April 2014) two key components had to take place quickly: 1) process the visa documents through the English Language Institute at Texas A\&M University; 2) match students with faculty hosts for the research portion of the program.

The English Language Institute processed the visa documents within one week, the Look College sent the documents via FedEx to CANIETI who worked with the US Embassy to ensure expedited processing of the students' visas. In the meantime, the Look College matched students with the faculty members for the research portion of the program. This was a very time consuming and labor intensive process. Students were listed on a spreadsheet divided into seven tabs. The tabs were related to specific research areas: robotics; 3-D printing, internet of things, cloud and mobile; autonomous vehicles; automation of knowledge, and miscellaneous.

The spreadsheet, which contained the name of the students and a brief description of the student's interest, was shared with faculty members in the Look College. Rather than contacting 
all faculty members in the college, a pre-matching was prepared with the help of the faculty members involved in the program. The faculty members indicated the student(s) he/she would like to host. A few department heads and the faculty champion helping the program assisted by suggesting names of potential faculty hosts as well. Lessons learned during this process were: 1 ) we need more information on the student, such as transcripts and a more focused research statement; 2) a website or interactive database should be created to better manage the process and make it less labor intensive; 3 ) additional time should be allowed for the matching; 4) and faculty information should be shared with the students to allow student empowerment.

The 50 students arrived a week before the English classes started. During that first week in the US, the students attended orientation sessions, toured the campus and city, took the English placement exam, and met with their faculty host. Knowing the challenges students faced during the pilot program, a more targeted orientation will be arranged focusing on the cultural and academic aspects. For example, medical situations arose and the students either called 911 for an ambulance or proceeded directly to the emergency room. While these situations occurred after hours and the students had the proper health insurance, it resulted in astronomical medical bills. Special emphasis will be added to the orientation to better inform students where and how to contact the clinics in town and when and why to avoid the hospitals. Another example, on the academic side, is the work-independency that is expected from graduate students when it comes to research. Some of the students anticipated more guidance and/or daily contact with the faculty host and felt a little lost at the beginning. Better preparing the students for that environment will allow them to engage in the research project and adjust to the lab environment more quickly.

The program was designed to provide intensive language training in the morning. For that, the collaboration of Texas A\&M University's English Language Institute was crucial. The English Language Institute integrated the 50 students into their regular summer session while creating a tailored TOEFL preparation class for the group and designating conversation partners that would address each student's English weakness. Students took an assessment test at the beginning and were placed in classes appropriate to their levels addressing their needs. The goal was not only to improve their English language skills, but also prepare them to take the TOEFL and meet the minimum required by the university, which is a score of 80 on the iBT TOEFL.

The program was also designed to provide students with GRE training and research immersion. The GRE training took place during the first five weeks of the program. It was two hours twice a week (Mondays and Wednesdays from 1pm to 3pm). The GRE training is part of another program of the Look College designed to recruit domestic students to graduate school. Students received the GRE book and were integrated into the same class as the domestic students. This was the first time most of the students were exposed to the GRE and this type of test. They took an unofficial GRE test prior to the program, but this is not a familiar type of test for Mexican students. According to the students, this training helped them to better understand and approach the test. For the students whose English level was lower than expected, this was very challenging. It is important to note this was an intensive program and the GRE training took time from their research work. One adjustment being considered for 2015 is offering the GRE training on Saturday mornings. This will allow students to only focus on English language training and research during the week, and allow them to spend more time in the lab with their research group. 
The research afternoon was very intensive. Along with their faculty host, students developed a research plan for the duration of the program. Students had only about 4 hours each day to work on those projects. The 50 Mexican students were integrated into the research group of the faculty host and were expected to work independently as the graduate students in the US. All of the students were very strong academically and motivated which enabled those with lower English levels succeed in their research component. The lab environment in the US is different than in Mexico as mentioned before, so students had to adjust. Some of the students adjusted very fast while others struggled a little on the first few weeks. However, most of the students had a positive experience or perception of their lab work, which is commented on the next session of this paper on student mid-program evaluation.

The logistics of the program should not be downplayed. Extra coordination took place to find housing, transportation, purchase books, and schedule official TOEFL and GRE testing. Despite the late start of the program, we were able to find one housing complex with space to accommodate all 50 students. The coordination with the housing was important as they also provided transportation. This included daily transfer to and from the university and Saturday transport to the grocery store. Scheduling the TOEFL was challenging because in College Station where Texas A\&M University is located, not enough spots were available for all 50 students and arrangements had to be made to transport students to three additional sites nearly 100 miles away. This was important because students needed to take the TOEFL before returning to Mexico, as their cities in Mexico did not offer the TOEFL and the application deadline for the graduate programs at Texas A\&M University was fast approaching. Earlier TOEFL scheduling is needed to allow students to take the test in the same city or on different dates all in the same town. The Look College is exploring an option for ETS to certify a test site on the Texas A\&M University campus to allow all students to take the exam in the same location. The GRE was easier to coordinate as more dates were available.

Student Feedback on Midterm Evaluation

CANIETI and Yucatan conducted a midterm interview with the students; one of the questions asked of the students was "What was your English level when you arrived and what is your English level now?” On table 1 below; it is noted from the students' perspectives, they improved their English. Initially, 28\% categorized themselves as beginners, while half way through the program, this drops down to only 5\%. The intermediate stayed the same, but that is because some of the beginners' levels increased to intermediate and some of the intermediate increased to advanced level. Only 23\% of the students felt they were in the advanced level before the program, while half way through the program $46 \%$ felt they were advanced level.

Table 1: Students' Perceived English Level Table

\begin{tabular}{|l|c|c|}
\hline $\begin{array}{l}\text { Students' Perception of English } \\
\text { Level }\end{array}$ & $\begin{array}{c}\text { Initial English } \\
\text { Level }\end{array}$ & $\begin{array}{c}\text { Midterm English } \\
\text { Level }\end{array}$ \\
\hline$\%$ of Students in advanced level & $23 \%$ & $46 \%$ \\
\hline$\%$ of Students in intermediate level & $49 \%$ & $49 \%$ \\
\hline$\%$ of Students in beginners level & $28 \%$ & $5 \%$ \\
\hline
\end{tabular}


Hamdan (2012) describes the importance of Krashen's affective filter hypothesis and concludes that a suitable environment in which aspects that may be considered mundane to some extent, including course schedules or group integration, has a direct impact on students, reducing their anxiety; even more so if class activities allows students direct interaction with their social and academic environment, which will result in a positive performance in learning a language ${ }^{[12]}$. These dynamics were observed in the classes taken by students in the English Language Institute at Texas A\&M University, where most mentioned that taking English classes and applying their knowledge in activities that appeal to them made a difference in feeling that their English proficiency had improved. This result was also measured using the official TOEFL test they took in early August 2014. The official TOEFL scores are presented in table 2 and listed as postTOEFL.

Upon arrival to the English Language Institute, a diagnostic test was administered to determine proficiency levels in the following areas: grammar, listening, reading and vocabulary. This, in theory, would allow students to strengthen their weaknesses. Their oral expression skills were not evaluated. The director of the English Language Institute noted that since time to prepare the courses was short, not every student's needs were met. For the 2015 program the same diagnostic test will be given to the students at the end of the program. Therefore, in addition to comparing the pre-unofficial TOEFL and post-official TOEFL, we will also compare the pre and post English diagnostics test.

In regards to student's research engagement, the midterm evaluation interview conducted by CANIETI and Yucatan showed that $44 \%$ of the students were very satisfied with the research project they were developing in the lab, while $46 \%$ said they were satisfied and only $10 \%$ reported being "less satisfied". Another interesting result from the midterm interview was that $92 \%$ of the students said they now consider new perspectives in relation to their project that they would not have found if they had stayed in Mexico. Also, the midterm evaluation showed that $82 \%$ of the students were very motivated to pursue a graduate degree and $18 \%$ motivated.

Application to the Graduate Program

This part was also labor intensive and required special coordination not only to get the students' application completed, but to coordinate with CONACYT's scholarship deadlines. To help with the Texas A\&M University application, students attended a workshop on the application process. As a follow up, they had a point of contact in the university who guided them through the process. Once the TOEFL and GRE scores were received, along with the program and term students would like to apply, the list of students was separated into three groups. The first group of 11 students was ready (graduation and test scores) to apply for spring 2015. The next group of 22 students were applicant contenders for fall 2015, but would have to retake one or both of the exams. The third group of 17 students required an alternative route (a program in Mexico or additional training to achieve the scores necessary for admission consideration). Table 2 below shows the three groups. 
Table 2: Application Group Table

\begin{tabular}{|c|c|c|c|c|c|c|c|c|}
\hline Student * & $\begin{array}{l}\text { Post } \\
\text { TOEFL }\end{array}$ & $\begin{array}{c}\text { Post GRE } \\
\text { V }\end{array}$ & $\begin{array}{c}\text { Post GRE } \\
\text { Q }\end{array}$ & Group & Department Confirmed & $\begin{array}{c}\text { Degree } \\
\text { Programs }\end{array}$ & Accepted & Note \\
\hline 1 & 100 & 151 & 152 & 1 & Computer Science \& Engineering & MS & Spring 2015 & \\
\hline 2 & 99 & 148 & 150 & 1 & Petroleum Engineering & $\mathrm{ME}$ & Spring 2015 & \\
\hline 3 & 97 & 148 & 158 & 1 & Computer Science \& Engineering & MS & Spring 2015 & \\
\hline 4 & 95 & 148 & 153 & 1 & Biomedical Engineering & $\mathrm{PhD}$ & Spring 2015 & \\
\hline 5 & 91 & 145 & 161 & 1 & Mathematics (interdisciplinary) & $\mathrm{PhD}$ & Spring 2015 & \\
\hline 6 & 90 & 144 & 150 & 1 & Aerospace Engineering & MS & Fall 2015 & Conditional \\
\hline 7 & 87 & 142 & 154 & 1 & Educational Technology & MS & Denied & \\
\hline 8 & 84 & 148 & 160 & 1 & Computer Science \& Engineering & $\mathrm{PhD}$ & Spring 2015 & \\
\hline 9 & 82 & 136 & 161 & 1 & Electrical \& Computer Engineering & $\mathrm{PhD}$ & Spring 2015 & \\
\hline 10 & 80 & 144 & 154 & 1 & Computer Science \& Engineering & MS & Denied & Reapplying \\
\hline 11 & 104 & 154 & 150 & 1 & Electrical \& Computer Engineering & $\mathrm{PhD}$ & Spring 2015 & \\
\hline 12 & 101 & 143 & 158 & 2 & Electrical \& Computer Engineering & $\mathrm{PhD}$ & Fall 2015 & \\
\hline 13 & 87 & 130 & 153 & 2 & Electrical \& Computer Engineering & $\mathrm{PhD}$ & Fall 2015 & \\
\hline 14 & 81 & 145 & 152 & 2 & Biomedical Engineering & $\mathrm{ME}$ & & Applying \\
\hline 15 & 68 & 144 & 161 & 2 & Industrial \& Systems Engineering & $\mathrm{ME}$ & & Applying \\
\hline 16 & 96 & 145 & 150 & 2 & Aerospace Engineering & $\mathrm{ME}$ & & \\
\hline 17 & 90 & 145 & 148 & 2 & Mechanical Engineering & $\mathrm{PhD}$ & & Applying \\
\hline 18 & 89 & 144 & 148 & 2 & Computer Science \& Engineering & MS & & \\
\hline 19 & 87 & 145 & 151 & 2 & Electrical \& Computer Engineering & MS & & \\
\hline 20 & 81 & 146 & 151 & 2 & Biomedical Engineering & $\mathrm{ME}$ & & \\
\hline 21 & 81 & 143 & 145 & 2 & Manufacturing and Mech Eng Tech & $\mathrm{ME}$ & & \\
\hline 22 & 80 & 141 & 143 & 2 & Computer Science \& Engineering & MS & & \\
\hline 23 & 79 & 139 & 149 & 2 & Civil Engineering & $\mathrm{PhD}$ & & Applying \\
\hline 24 & 78 & 151 & 151 & 2 & Computer Science \& Engineering & $\mathrm{ME}$ & & \\
\hline 25 & 78 & 148 & 148 & 2 & Biomedical Engineering & $\mathrm{ME}$ & & Applying \\
\hline 26 & 76 & 135 & 143 & 2 & Electrical \& Computer Engineering & MS & & \\
\hline 27 & 75 & 146 & 148 & 2 & Computer Science \& Engineering & MS & & Applying \\
\hline 28 & 75 & 149 & 149 & 2 & Electrical \& Computer Engineering & MS & & \\
\hline 29 & 70 & 143 & 144 & 2 & Mechanical Engineering & $\mathrm{PhD}$ & & \\
\hline 30 & 67 & 141 & 146 & 2 & Computer Science \& Engineering & MS & & \\
\hline 31 & 66 & 140 & 144 & 2 & Aerospace Engineering & MS & & \\
\hline 32 & 64 & 143 & 153 & 2 & Electrical \& Computer Engineering & $\mathrm{ME}$ & & \\
\hline 33 & 61 & 140 & 150 & 2 & Computer Science \& Engineering & $\mathrm{ME}$ & & \\
\hline 34 & 64 & 134 & 146 & 3 & Civil Engineering & $\mathrm{PhD}$ & & \\
\hline 35 & 63 & 139 & 148 & 3 & Civil Engineering & MS & & \\
\hline 36 & 63 & 141 & 146 & 3 & Computer Science \& Engineering & $\mathrm{ME}$ & & \\
\hline 37 & 63 & 143 & 148 & 3 & Civil Engineering & MS & & \\
\hline 38 & 62 & 141 & 147 & 3 & Computer Science \& Engineering & MS & & \\
\hline 39 & 62 & 140 & 143 & 3 & Mechanical Engineering & $\mathrm{ME}$ & & \\
\hline 40 & 60 & 135 & 145 & 3 & Civil Engineering & $\mathrm{PhD}$ & & \\
\hline 41 & 59 & 139 & 142 & 3 & Computer Science \& Engineering & MS & & \\
\hline 42 & 56 & 140 & 140 & 3 & Electrical \& Computer Engineering & $\mathrm{ME}$ & & \\
\hline 43 & 49 & 139 & 136 & 3 & Computer Science \& Engineering & MS & & \\
\hline 44 & 49 & 136 & 144 & 3 & Electrical \& Computer Engineering & $\mathrm{ME}$ & & \\
\hline 45 & 49 & 138 & 142 & 3 & Computer Science \& Engineering & $\mathrm{ME}$ & & \\
\hline 46 & 46 & 142 & 149 & 3 & Electrical \& Computer Engineering & $\mathrm{ME}$ & & \\
\hline 47 & 44 & 139 & 149 & 3 & Computer Science \& Engineering & $\mathrm{ME}$ & & \\
\hline 48 & 37 & 139 & 140 & 3 & Electrical \& Computer Engineering & $\mathrm{ME}$ & & \\
\hline 49 & 36 & 130 & 137 & 3 & Computer Science \& Engineering & MS & & \\
\hline 50 & 54 & 140 & 145 & 3 & Aerospace Engineering & MS & & Applying \\
\hline
\end{tabular}

* Students' names were substituted by numbers. Student 1 is the same student through the study.

Since the deadline for the graduate degree application and scholarship application were approaching and some of the students still had to retake tests, the Look College worked closely with the sponsored student office and with the academic departments for a conditional 
acceptance letter. This letter contained three conditions: the student met the required TOEFL, the student met the required GRE, and the student was awarded the scholarship from Mexico. The department was able to provide this letter to the students whose transcripts and academic work were strong enough to be accepted into the department in case the test scores were met. In this regard, most of the students received a recommendation letter from their summer host faculty which played an important role in the acceptance decision of the students in the departments. With this letter, students were able to apply to the CONACYT scholarship.

Program Results

As a result of this pilot program, most students' scores significantly improved on the TOEFL and GRE. On the TOEFL, 37 out 50 students improved their scores, and 21 students earned an 80 or above score (42\% of the students) compared to 13 students before the program (26\% of the students). It is important to note the pre-TOEFL was not an official TOEFL test but a mock test. With regard to the GRE Verbal section, 27 students' scores improved while 47 students' scores improved on the Quantitative section. The pre-GRE test was also a mock test. This is due to the high price of sitting the official TOEFL and GRE exams and the lack of test sites in the Mexican cities where students reside. Table 3 outlines the pre and post TOEFL and GRE score of the students.

In relation to grad school applications and acceptance, the pilot program has shown positive results. Out of the 50 students who participated in the summer 2014 pilot program, eight students have been admitted and are currently enrolled as sponsored students for the 2015 spring semester for their master or PhD degree. Two students have already been admitted for fall 2015 and 15 additional students are completing their application for the fall 2015 semester. With the 10 students already admitted, we currently have a $20 \%$ success rate on acceptance. Considering this was the first year of the program and 23 students arrived on site with a TOEFL score lower than 60 , this program has achieved the organizers and sponsors goals for the first year.

From the Look College's perspective, with the 10 students accepted this is an increase of 31.5\% in graduate students from Mexico in the Look College at Texas A\&M University. If by fall 2015 we have a total of 25 students enrolled out of the 50 , this will be a $78 \%$ increase. Compared to the results presented in some of the literature, this outcome is very positive. For example, the University of Minnesota-Twin Cities established a recruiting committee that met two to three times a semester to identify the needs and develop a plan of action, and enrollment increased by $19 \%$ from 2005 to $2006^{[3]}$. Another example is the University of North Carolina-Charlotte (UNC-C) where a strong institutional commitment and the establishment of mutually beneficial partnerships around the world led to a $42 \%$ increase in international undergraduate student numbers between 2005 and $2007^{[3]}$.

From the host faculty perspective, we can also say this was a positive experience. At the end of the program two simple questions were sent to the faculty hosts: Would you host this student in your program if he/she were to apply for the MS/PhD program; and are you interested in supervising students next summer. Out of 21 faculty hosts, 16 replied "yes" to both questions, two replied "no" to both questions and three did not respond. 
Table 3: Pre and Post TOEFL and GRE Scores

\begin{tabular}{|c|c|c|c|c|c|c|c|c|c|c|c|}
\hline Student * & Department & $\begin{array}{c}\text { Degree } \\
\text { Program }\end{array}$ & $\begin{array}{c}\text { Pre } \\
\text { TOEFL }\end{array}$ & $\begin{array}{c}\text { Post } \\
\text { TOEFL }\end{array}$ & $\begin{array}{l}\text { TOEFL } \\
\text { Change }\end{array}$ & \begin{tabular}{|c|} 
Pre GRE \\
$\mathrm{V}$
\end{tabular} & $\begin{array}{c}\text { Post GRE } \\
\text { V }\end{array}$ & $\begin{array}{c}\text { GRE V } \\
\text { Change }\end{array}$ & $\begin{array}{c}\text { Pre GRE } \\
\mathbf{Q}\end{array}$ & $\begin{array}{c}\text { Post GRE } \\
\mathbf{Q}\end{array}$ & $\begin{array}{l}\text { GRE Q } \\
\text { Change }\end{array}$ \\
\hline 1 & Computer Science \& Engineering & MS & 94 & 100 & 6 & 147 & 151 & 4 & 142 & 152 & 10 \\
\hline 2 & Petroleum Engineering & $\mathrm{ME}$ & 101 & 99 & -2 & 156 & 148 & -8 & 147 & 150 & 3 \\
\hline 3 & Computer Science \& Engineering & MS & 59 & 97 & 38 & 149 & 148 & -1 & 144 & 158 & 14 \\
\hline 4 & Biomedical Engineering & $\mathrm{PhD}$ & 90 & 95 & 5 & 147 & 148 & 1 & 143 & 153 & 10 \\
\hline 5 & Mathematics (interdisciplinary) & PhD & 79 & 91 & 12 & 147 & 145 & -2 & 149 & 161 & 12 \\
\hline 6 & Aerospace Engineering & $\mathrm{MS}$ & 82 & 90 & 8 & 145 & 144 & -1 & 144 & 150 & 6 \\
\hline 7 & Educational Technology & MS & 83 & 87 & 4 & 144 & 142 & -2 & 141 & 154 & 13 \\
\hline 8 & Computer Science \& Engineering & PhD & 89 & 84 & -5 & 147 & 148 & 1 & 152 & 160 & 8 \\
\hline 9 & Electrical \& Computer Engineering & $\mathrm{PhD}$ & 79 & 82 & 3 & 143 & 136 & -7 & 152 & 161 & 9 \\
\hline 10 & Computer Science \& Engineering & MS & 86 & 80 & -6 & 149 & 144 & -5 & 141 & 154 & 13 \\
\hline 11 & Electrical \& Computer Engineering & PhD & 85 & 104 & 19 & 152 & 154 & 2 & 141 & 150 & 9 \\
\hline 12 & Electrical \& Computer Engineering & $\mathrm{PhD}$ & 89 & 101 & 12 & 150 & 143 & -7 & 150 & 158 & 8 \\
\hline 13 & Electrical \& Computer Engineering & $\mathrm{PhD}$ & 82 & 87 & 5 & 144 & 130 & -14 & 146 & 153 & 7 \\
\hline 14 & Biomedical Engineering & $\mathrm{ME}$ & 70 & 81 & 11 & 141 & 145 & 4 & 144 & 152 & 8 \\
\hline 15 & Industrial \& Systems Engineering & $\mathrm{ME}$ & 84 & 68 & -16 & 137 & 144 & 7 & 153 & 161 & 8 \\
\hline 16 & Aerospace Engineering & $\mathrm{ME}$ & 103 & 96 & -7 & 148 & 145 & -3 & 134 & 150 & 16 \\
\hline 17 & Mechanical Engineering & $\mathrm{PhD}$ & 65 & 90 & 25 & 145 & 145 & 0 & 146 & 148 & 2 \\
\hline 18 & Computer Science \& Engineering & $\mathrm{MS}$ & 62 & 89 & 27 & 141 & 144 & 3 & 139 & 148 & 9 \\
\hline 19 & Electrical \& Computer Engineering & MS & 72 & 87 & 15 & 143 & 145 & 2 & 144 & 151 & 7 \\
\hline 20 & Biomedical Engineering & $\mathrm{ME}$ & 47 & 81 & 34 & 136 & 146 & 10 & 141 & 151 & 10 \\
\hline 21 & Manufacturing and Mech Eng Tech & $\mathrm{ME}$ & 52 & 81 & 29 & 139 & 143 & 4 & 142 & 145 & 3 \\
\hline 22 & Computer Science \& Engineering & MS & 62 & 80 & 18 & 137 & 141 & 4 & 139 & 143 & 4 \\
\hline 23 & Civil Engineering & $\mathrm{PhD}$ & 72 & 79 & 7 & 144 & 139 & -5 & 141 & 149 & 8 \\
\hline 24 & Computer Science \& Engineering & $\mathrm{ME}$ & 54 & 78 & 24 & 135 & 151 & 16 & 135 & 151 & 16 \\
\hline 25 & Biomedical Engineering & $\mathrm{ME}$ & 85 & 78 & -7 & 145 & 148 & 3 & 149 & 148 & -1 \\
\hline 26 & Electrical \& Computer Engineering & MS & 58 & 76 & 18 & 137 & 135 & -2 & 139 & 143 & 4 \\
\hline 27 & Computer Science \& Engineering & MS & 77 & 75 & -2 & 141 & 146 & 5 & 142 & 148 & 6 \\
\hline 28 & Electrical \& Computer Engineering & MS & 50 & 75 & 25 & 141 & 149 & 8 & 136 & 149 & 13 \\
\hline 29 & Mechanical Engineering & $\mathrm{PhD}$ & 65 & 70 & 5 & 137 & 143 & 6 & 146 & 144 & -2 \\
\hline 30 & Computer Science \& Engineering & MS & 49 & 67 & 18 & 138 & 141 & 3 & 141 & 146 & 5 \\
\hline 31 & Aerospace Engineering & MS & 55 & 66 & 11 & 144 & 140 & -4 & 143 & 144 & 1 \\
\hline 32 & Electrical \& Computer Engineering & $\mathrm{ME}$ & 43 & 64 & 21 & 147 & 143 & -4 & 149 & 153 & 4 \\
\hline 33 & Computer Science \& Engineering & $\mathrm{ME}$ & 60 & 61 & 1 & 135 & 140 & 5 & 131 & 150 & 19 \\
\hline 34 & Civil Engineering & $\mathrm{PhD}$ & 72 & 64 & -8 & 141 & 134 & -7 & 143 & 146 & 3 \\
\hline 35 & Civil Engineering & MS & 55 & 63 & 8 & 144 & 139 & -5 & 135 & 148 & 13 \\
\hline 36 & Computer Science \& Engineering & $\mathrm{ME}$ & 47 & 63 & 16 & 138 & 141 & 3 & 140 & 146 & 6 \\
\hline 37 & Civil Engineering & MS & 53 & 63 & 10 & 144 & 143 & -1 & 139 & 148 & 9 \\
\hline 38 & Computer Science \& Engineering & MS & 58 & 62 & 4 & 135 & 141 & 6 & 140 & 147 & 7 \\
\hline 39 & Mechanical Engineering & $\mathrm{ME}$ & 58 & 62 & 4 & 135 & 140 & 5 & 131 & 143 & 12 \\
\hline 40 & Civil Engineering & $\mathrm{PhD}$ & 41 & 60 & 19 & 135 & 135 & 0 & 138 & 145 & 7 \\
\hline 41 & Computer Science \& Engineering & MS & 31 & 59 & 28 & 141 & 139 & -2 & 132 & 142 & 10 \\
\hline 42 & Electrical \& Computer Engineering & $\mathrm{ME}$ & 43 & 56 & 13 & 136 & 140 & 4 & 134 & 140 & 6 \\
\hline 43 & Computer Science \& Engineering & MS & 43 & 49 & 6 & 132 & 139 & 7 & 131 & 136 & 5 \\
\hline 44 & Electrical \& Computer Engineering & $\mathrm{ME}$ & 55 & 49 & -6 & 130 & 136 & 6 & 135 & 144 & 9 \\
\hline 45 & Computer Science \& Engineering & $\mathrm{ME}$ & 41 & 49 & 8 & 139 & 138 & -1 & 131 & 142 & 11 \\
\hline 46 & Electrical \& Computer Engineering & $\mathrm{ME}$ & 52 & 46 & -6 & 141 & 142 & 1 & 137 & 149 & 12 \\
\hline 47 & Computer Science \& Engineering & $\mathrm{ME}$ & 59 & 44 & -15 & 137 & 139 & 2 & 140 & 149 & 9 \\
\hline 48 & Electrical \& Computer Engineering & $\mathrm{ME}$ & 34 & 37 & 3 & 132 & 139 & 7 & 163 & 140 & -23 \\
\hline 49 & Computer Science \& Engineering & MS & 46 & 36 & -10 & 135 & 130 & -5 & 137 & 137 & 0 \\
\hline 50 & Aerospace Engineering & MS & 58 & 54 & -4 & 136 & 140 & 4 & 140 & 145 & 5 \\
\hline
\end{tabular}

* Students' names were substituted by numbers. Student 1 is the same student through the study.

Key Ingredients

For the program to be implemented successfully, we first needed committed partners in Mexico CANIETI, Yucatan and Zacatecas - who were vested in the program and an integral part of the whole process. These partners were engaged before, during and after the program. The partners in Mexico were not only sponsors or financial supporters, but were engaged in the entire process and maintained constant contact with the students and our institution. It was truly a joint project.

On Texas A\&M University side, specific aspects were crucial. First, Mexico was defined by the leadership of the Look College as one of the international priorities. With the upper administration's support, we were encouraged to dedicate staff time to implement the program, 
and integrate the Mexican students into several of the college's programs, such as the GRE training. Second, we have a faculty champion who was engaged in the design and implementation of the program. Third, we had faculty members who were interested in hosting students from Mexico and who welcomed and dedicated time to those students during the summer. Fourth, The Engineering International Programs Office, which designed the program jointly with the Mexican partners and the faculty champion, was "responsible" for the implementation of the program at Texas A\&M University coordinating all aspects of the program from the Texas A\&M side (housing, faculty hosts, GRE training, weekly schedules, among others). Last, but not least, another key partner was the Texas A\&M University’s English Language Institute. As mentioned above, they processed the visas and integrated the students into their regular program while creating tailored activities.

In summary, this recruiting program was part of the strategic internationalization plan of the Look College. Rather than sending recruiting agents to Mexico, the college partnered with organizations in Mexico and developed a summer program to provide the necessary tools for students to apply and successfully gain admittance into graduate school. This type of program is expected to impact retention as both the student and the faculty host/institution have a solid understanding of the program and expected outcomes.

How to Improve

Even though the program had positive results, improvements can be made on the implementation and return on investment of this program. A few students arrived with English skills lower than expected. Twenty-five students scored below 50 (out of 100) on the English Language Institute's English Language Placement Exam (ELPE). On the unofficial TOEFL, 25 students scored 60 or lower. This limited the number of students who could improve their score to the 80 point minimum requirement by Texas A\&M University, and most universities in the US, within the 10 -week program. It also limited those students on their research projects. Nevertheless, the English training and cultural emersion were effective and at the end of the program, only 11 students scored below 60. The goal for the 2015 summer program is for all students to begin with an unofficial TOEFL of 60 or above. This will provide a higher return on investment for both sides.

Another area to be improved with more time and better coordination is the matching between the student and the faculty member. Besides additional time, it was determined that with the school transcript and a short description of the student's previous experience and future goals, a better match can be found.

A summary of lessons learned follows:

- Selection: Require a 60 point minimum on the TOEFL

- $\quad$ Faculty/Student research match: Begin matching earlier and utilize additional student information (transcript and research statement); a website or interactive database to increase the effectiveness of the process and make it less labor intensive. Additional time will allow the opportunity to be open to all faculty members in the college.

- Arrival orientation: The arrival orientation, besides the campus tour, should include a city tour, medical advice, cultural training, general lab expectations and a social event. 
- GRE: GRE training can be conducted on Saturdays for 6 weeks so it does not detract from the research internship.

- Application to MS or PhD Program: A workshop should be held 5 weeks into the program, and another at the end to guide students through the application process to enable submission prior to returning to Mexico. Open and maintain strong communication between CONACYT, Mexican state governments, Look College and Texas A\&M University to establish criteria and schedules to meet the requirements of all entities to facilitate smooth application and funding processes.

\section{Conclusion}

The summer program was created to address the barriers Mexican students face when applying for graduate programs in the United States. Partnering with key institutions in Mexico who select and sponsor the students ensures the best are being selected because both sides seek a high return on investment - in the short run, students who will be accepted into Look College graduate programs; in the long run, professionals who will positively impact the economic development of Mexico and will have solid partnerships at Texas A\&M University and the state of Texas.

As mentioned in many articles in the literature, international student recruitment was seen as a part of cultural activities, but now it is linked to economic development. This partnership and program is a reflection of that and this, we believe, is the key for success. The program reflects a recruitment plan linked to the strategic plan of the Look College and the economic development of Texas and Mexico. The model described in the paper could be replicated by other universities and other countries seeking to improve their human capacity by sending students for master and $\mathrm{PhD}$ degrees abroad.

\section{Acknowledgements}

With the conclusion of this paper it is important to acknowledge the key people who made this program possible.

For their vision and determination in creating new programs that will bring economic development to Mexico, and for sponsoring the TAMU-CANIETI 2014 Summer Program and commitment to continue in 2015: Victor Gutierrez, President of CANIETI; Alberto Munoz, Vice-President for Innovation, Science \& Technology, CANIETI Southeast; Ricardo Bello Bolio, Director of the Office for Higher Education of the state of Yucatan; Tomas Gonzalez, Director General of the Council for Science, Innovation and Technology of the state of Yucatan.

Dr. Zenon Medina-Cetina, Associate Professor of the Zachry Department of Civil Engineering at Texas A\&M University, for his vision in connecting his sponsor with Texas A\&M University for broader programs beyond his individual research. Also for his time, dedication, and involvement in the development and implementation of the 2014 program and the new version of it for summer 2015.

Last, but not least, Meghan Alexander, Assistant Director for Engineering International Programs at Texas A\&M University; Martha Ortega, Director of Partnership for CANIETI; 
Victor Camara, Strategic Partnerships and Planning Coordinator of the Office for Higher Education of State of Yucatan; and Angela Gamboa, Program Coordinator of the Office for Higher Education of State of Yucatan; for their hard work in making the summer 2014 program happen and their dedication for the summer 2015 continuation.

Bibliography

This paper has been accepted in the International Division of the $122^{\text {nd }}$ ASEE Annual Conference \& Exposition (June 14-17, 2015 Seattle WA - Paper ID \#12719). It will be presented in the poster session and will be published with the proceedings of the conference.

[1] S. K. Srivastava, S. A. K. and A. R. Minerick, "Recruitment and Retention of International Graduate Students in US Universities," International journal of Engineering Education, vol. 26, no. 6, p. 1561-1574, 2010.

[2] F. Najafi, D. Jet and N. Safai, "A global model for higher educational institutions to increase the enrollment of minority and international students," in ASEE Annual Conference and Exposition, Pittsburgh, PA, 2008.

[3] O. Özturgut, "Best Practices in Recruiting and Retaining International Students in the U.S.," Current Issues in Education, vol. 16, no. 2 - ISSN 1099-839X, p. Retrieved from http://cie.asu.edu/ojs/index.php/cieatasu/article/view/1213, 2013.

[4] CANIETI, "Becas Extrangero CONACYT," Unpublished, Mexico City, 2015.

[5] Dwight Look College of Engineering , "Dwight Look College of Engineering Data Report," Umpublished, College Station, 2014.

[6] Institute of International Education, "Open Doors 2014 Data," Institute of International Education, 17 November 2014. [Online]. Available: http://www.iie.org/Research-and-Publications/Open-Doors/Data. [Accessed 13 March 2015].

[7] R. Becker and R. Kolster, "International student recruitment: policies and developments in selected countries," Netherlands Organisation for International Cooperation in Higher Education, 2012.

[8] L. Brown, "A failure of communication on the cross-cultural campus," Journal of Studies in International Education, vol. 13, no. 4, pp. 439-454, 2009.

[9] C. D. W. Goodwin and M. Nacht, " Absence of decision: Foreign students in American colleges and universities: A report on policy formation and the lack thereof," Institute of International Education, New York, 1983.

[10] E. Katz, "Recruiting International Graduate Students Today," NAFSA: Association of International Educators, vol. 15, no. 4 ISSN: 1059-4221, pp. 54-56,58, 2006. 
[11] Texas A\&M University, "University Metrics - Applied, Admitted, \& Enrolled," [Online]. Available: https://accountability.tamu.edu/content/university-metrics-applied-admitted-enrolled. [Accessed 20 November 2014].

[12] A. A. S. Hamdam, "Los Modelos de Adquisición y Enseñanza en una Segunda Lengua," Avances en supervisión Educativa, vol. 16, no. http://www.adide.org/revista/images/stories/pdf_16/ase16_art02.pdf, pp. 115, 2012.

Other References

Altbach, P. G. (1991). Impact and adjustment: Foreign students in comparative perspective. Higher Education, 21(3), 305-323.

Altbach, P. G., \& Knight, J. (2007). The internationalization of higher education: Motives and realities. Journal of Studies in International Education, 11(3-4), 290-305.

Bolsmann, C., \& Miller, H. (2008). International student recruitment to universities in England: Discourse, rationale and globalization. Globalization, Societies and Education, 6(1), 75-88. 